\title{
INOCULATION AND ISOLATION OF PLANT GROWTH-PROMOTING BACTERIA IN MAIZE GROWN IN VITÓRIA DA CONQUISTA, BAHIA, BRAZIL
}

\author{
Joelma da Silva Santos(1)*, Tarciana de Oliveira Viana(2), Cristina Meira de Jesus(1), Vera \\ Lúcia Divan Baldani( ${ }^{(3)}$ and Joilson Silva Ferreira(4)
}

\footnotetext{
(1) Universidade Estadual do Sudoeste da Bahia, Programa de Pós-graduação em Agronomia, Campus Vitória da Conquista, Vitória da Conquista, Bahia, Brasil.

(2) Universidade Estadual do Norte Fluminense, Programa de Pós-graduação em Produção Vegetal, Campo dos Goytacazes, Rio de Janeiro, Brasil.

(3) Empresa Brasileira de Pesquisa Agropecuária, Centro Nacional de Pesquisa em Agrobiologia, Seropédica, Rio de Janeiro, Brasil.

(4) Universidade Estadual do Sudoeste da Bahia, Departamento de Fitotecnia e Zootecnia, Vitória da Conquista, Bahia, Brasil.

* Corresponding author.

E-mail: joelmassbio@gmail.com
}

\begin{abstract}
Maize is among the most important crops in the world. This plant species can be colonized by diazotrophic bacteria able to convert atmospheric $\mathrm{N}$ into ammonium under natural conditions. This study aimed to investigate the effect of inoculation of the diazotrophic bacterium Herbaspirillum seropedicae (ZAE94) and isolate new strains of plant growth-promoting bacteria in maize grown in Vitória da Conquista, Bahia, Brazil. The study was conducted in a greenhouse at the Experimental Area of the Universidade Estadual do Sudoeste da Bahia. Inoculation was performed with peat substrate, with and without inoculation containing strain ZAE94 of $H$. seropedicae and four rates of $\mathrm{N}$, in the form of ammonium sulfate $\left(0,60,100\right.$, and $\left.140 \mathrm{~kg} \mathrm{ha}^{-1} \mathrm{~N}\right)$. After 45 days, plant height, dry matter accumulation in shoots, percentage of $\mathrm{N}$, and total $\mathrm{N}$ (NTotal) were evaluated. The bacteria were isolated from root and shoot fragments of the absolute control; the technique of the most probable number and identification of bacteria were used. The new isolates were physiologically characterized for production of indole acetic acid (IAA) and nitrogenase activity. We obtained 30 isolates from maize plants. Inoculation with strain ZAE94 promoted an increase of $14.3 \%$ in shoot dry mass and of $44.3 \%$ in NTotal when associated with the rate $60 \mathrm{~kg} \mathrm{ha}^{-1} \mathrm{~N}$. The strains N11 and N13 performed best with regard to IAA production and J06, J08, J10, and N15 stood out in acetylene reduction activity, demonstrating potential for inoculation of maize.
\end{abstract}

Keywords: diazotrophic bacteria, Herbaspirillum spp., Zea mays. 


\title{
RESUMO: INOCULAÇÃO E ISOLAMENTO DE BACTÉRIAS PROMOTORAS DO CRESCIMENTO VEGETAL EM MILHO CULTIVADO EM VITÓRIA DA CONQUISTA, BAHIA
}

\begin{abstract}
O milho é uma das culturas agrícolas mais importantes do mundo. Essa espécie vegetal pode ser colonizada por bactérias diazotróficas capazes de reduzir $N$ atmosférico a amônio em condições naturais. Objetivaram-se estudar o efeito da inoculação da bactéria diazotrófica Herbaspirillum seropedicae (ZAE94) e isolar novas estirpes de bactérias promotoras do crescimento vegetal na cultura do milho cultivada em Vitória da Conquista, BA. O estudo foi conduzido em casa de vegetação na Área Experimental da Universidade Estadual do Sudoeste da Bahia. A inoculação foi realizada com veículo turfoso com presença e ausência de inoculação contendo a estirpe ZAE94 de H. seropedicae e quatro doses de $\mathrm{N}$, na forma de

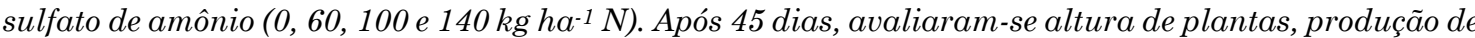
matéria seca da parte aérea, o percentual de $\mathrm{N}$ e $\mathrm{N}$ total. O isolamento foi realizado a partir de fragmentos das raízes e parte aérea da testemunha absoluta, e utilizaram-se a técnica do número mais provável e a identificação das bactérias. Os novos isolados foram caracterizados fisiologicamente quanto à produção de ácido indol acético (AIA) e atividade da nitrogenase (ARA). Foram obtidos 30 isolados de plantas de milho. A inoculação da estirpe ZAE94 promoveu aumentos de 14,3\% na produção de matéria seca da

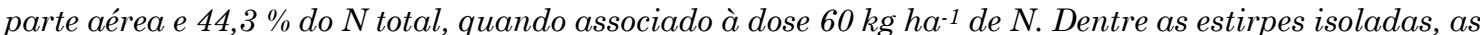
N11 e N13 se destacaram quanto à produção de AIA; e as J06, J08, J10 e N15, para a ARA, apresentando potencial para inoculação na cultura milho.
\end{abstract}

Palavras-chave: bactérias diazotróficas, Herbaspirillum spp., Zea mays.

\section{INTRODUCTION}

Maize (Zea mays L.) is among the most important crops in the world. In Brazil, this grain is significant both in the economic and the social fields, being used as food and feed, aside from serving as raw material in a diverse food processing procedures.

Of the whole national maize production, about 70 to $80 \%$ of the grain yield is used in the feed industry (Kwiatkowski and Clemente, 2009). The South, Southeast, and Central-West regions account for $90 \%$ of the Brazilian production, with the second largest cultivated area, behind only soybean (CONAB, 2013).

Nitrogen $(\mathrm{N})$ is among the major cell constituents and a crucial element for all living organisms (Soratto et al., 2010). Nitrogen availability is a limiting factor in agricultural productivity. It is one of the nutrients absorbed in greater quantity by crops. In maize, it influences the grain yield directly (Amado et al., 2002).

Although $\mathrm{N}$ represents around $78 \%$ of all atmospheric gases, plants cannot use it directly as a nutrient, due to the triple covalent bond between the two atoms of atmospheric $\mathrm{N}_{2}$ to produce ammonium (Hungria et al., 2001).

Among the natural processes contributing to $\mathrm{N}$ supply of the soil environment, biological $\mathrm{N}$ fixation is the most important. This reaction occurs by the action of diazotrophic bacteria that have the nitrogenase enzyme, able to break the triple covalent bond between the two atoms of atmospheric $\mathrm{N}$ and reduce them to ammonium, under natural conditions (Reis and Teixeira, 2005). The use of diazotrophic bacteria seem to be a promising strategy to reduce dependence on synthetic $\mathrm{N}$ fertilizers (Conceição et al., 2009). The species Herbaspirillum seropedicae, described by Baldani et al. (1986), comprises endophytic diazotrophic bacteria, mandatory, gram-negative, microaerobic, which are able to use various $\mathrm{C}$ sources.

Studies have demonstrated a positive effect of inoculation with diazotrophic bacteria in several commercially important crops (Baldani et al., 2000; Viana, 2012), e.g., rice (Cavallet et al., 2000; Alves, 2007), maize (Sala et al., 2008) and wheat.

According to Moreira et al. (2010), the contribution of biologically fixed $\mathrm{N}$ on Poaceas is estimated at 25 to $50 \mathrm{~kg} \mathrm{ha}^{-1} \mathrm{yr}^{-1}$, equivalent to the average supply of $17 \%$ of the demand required by these crops. Therefore, since major global territories are used for the cultivation of various cereals, indispensable to human and animal diet, the supply of $17 \%$ of the crop requirement by biological $\mathrm{N}$ fixation (BNF) would represent gains both in economic and environmental terms.

The significance of this study for maize, as well as the other Poaceas in Northeastern Brazil, is due to great economic and social relevance of this cereal, since it is widely grown by family farmers. Thus, the studies focused on BNF may represent a strategy to reduce the use of synthetic $\mathrm{N}$ fertilizers, thus decreasing economic costs and environmental impacts. Given the above, the isolation and characterization of diazotrophic bacteria found under the local edaphoclimatic conditions, may contribute to greater gains in $\mathrm{BNF}$, since the local 
isolates are already adapted to the conditions and must therefore be evaluated under field condition, both in maize and the other Poaceas.

This article aimed to investigate the effect of inoculation of the diazotrophic bacterium $H$. seropedicae (ZAE94) and isolate new strains of plant growth-promoting bacteria in maize grown in Vitória da Conquista, Bahia, Brazil.

\section{MATERIAL AND METHODS}

\section{Effect of inoculation of the diazotrophic bacterium $H$. seropedicae}

The experiment was conducted in a greenhouse in the campus of the Universidade Estadual do Sudoeste da Bahia (UESB), in Vitória da Conquista (lat $14^{\circ} 51^{\prime} \mathrm{S}$, long $40^{\circ} 50^{\prime} \mathrm{W}$, on average $928 \mathrm{~m}$ asl), with a total annual rainfall of $750 \mathrm{~mm}$ (Brasil, 1992).

The soil used in the experiment was taken from the 0-20 $\mathrm{cm}$ layer, horizon A of a Yellow Latosol (Oxisol). The soil chemical analysis showed the following results: $\mathrm{pH}\left(\mathrm{H}_{2} \mathrm{O}\right)=5.4 ; \mathrm{P}=2 \mathrm{mg} \mathrm{dm}^{-3}$; $\mathrm{K}^{+}=0.10 \mathrm{cmol}_{\mathrm{c}} \mathrm{dm}^{-3}$; organic matter $(\mathrm{OM})=22 \mathrm{~g} \mathrm{dm}^{-3}$. Corrections were made according to the Soil Fertility Commission of the State of Minas Gerais (Alvarez $\mathrm{V}$ and Ribeiro, 1999). All treatments received rates of $\mathrm{P}$ and $\mathrm{K}$ according to the crop requirements, considering the soil $\mathrm{OM}$ content.

The experimental units consisted of pots containing $9.0 \mathrm{dm}^{3}$ soil. The experimental design was completely randomized in a $2 \times 4$ factorial scheme, with and without inoculant of strain ZAE94 and four $\mathrm{N}$ rates $\left(0,60,100\right.$, and $\left.140 \mathrm{~kg} \mathrm{ha}^{-1} \mathrm{~N}\right)$ in the form of ammonium sulfate with five replications.

Inoculation took place with peat substrate containing strain ZAE94 (BR 11417) of $H$. seropedicae with an established population of $10^{9}$ cells g-1 of inoculant for inoculation treatments, at a proportion of $250 \mathrm{~g}$ of inoculant per $10 \mathrm{~kg}$ of maize seed. Four seeds of the maize hybrid AG 1051 were sown per pot. The distribution of $\mathrm{N}$ fertilization was divided in three times, i.e. $20 \%$ at sowing, $20 \% 15$ days after planting (DAP), and $60 \% 20$ DAP. Thinning was done $18 \mathrm{DAP}$, keeping two plants per pot.

Data were collected 45 DAP, and the agronomic parameters evaluated were plant height, shoot dry weight, nitrogen percentage (N\%), and total nitrogen (NTotal), the latter determined by Kjeldahl's digestion, as described by Nogueira and Souza (2005).

The data were subjected to homogeneity and normality tests and variance analysis; mean values were compared by Tukey's test at $5 \%$ significance, using software Sisvar version 4.0 (Ferreira, 2000).
Linear and quadratic regressions were performed to compare $\mathrm{N}$ rates.

\section{Isolation and morphological and physiological characterization of diazotrophic bacteria}

The diazotrophic bacteria were isolated from maize plants, absolute control, grown in pots in a greenhouse for 45 days. Then, the plant material was sent to the laboratory of grasses of the Empresa Brasileira de Pesquisa Agropecuária - Centro Nacional de Pesquisa em Agrobiologia (Embrapa Agrobiology), in Seropédica, Rio de Janeiro, Brazil, for isolation.

Isolation and counting were performed as proposed by Döbereiner et al. (1995), in samples of roots and shoots (leaf and stem) of maize plants, using $5 \mathrm{~g}$ of each fragment. The plant material was added to $45 \mathrm{~mL}$ of saline solution and ground in a blender. Serial dilutions of $10^{-3}$ to $10^{-7}$ were made and inoculated in semisolid, $\mathrm{N}$-free culture media (JNFb for Herbaspirillum seropedicae, NFb for Azospirillum spp., JMV for Burkholderia, and LGI for A. amazonense).

Diazotrophic bacteria populations were counted based on the most probable number (MPN), using McCrady's table for three replication per dilution (Döbereiner et al., 1995). After purification, the isolates were morphological characterized in specific solid media. Characteristics such as size, shape, edge, surface, elevation, transparency, and chrome genesis of the colonies (Döbereiner et al., 1995) were observed. Strains of $H$. seropedicae (ZAE94) and $A$. brasilense (Sp245), from the collection of diazotrophic bacteria cultures of Embrapa Agrobiology, were used as growth patterns, being grown and characterized under the same conditions.

For the physiological characterization, based on the production of indole acetic acid (IAA), the microplate method was used as described by Sarwar and Kremer (1995). Pure isolate colonies were replicated in tubes containing DYGS medium, where they were grown at $30^{\circ} \mathrm{C}$ for $24 \mathrm{~h}$ under constant agitation (150 rpm). The concentration of indole compounds was determined by a calibration curve prepared with serial dilutions of IAA patterns (0-50 $\left.\mathrm{gg} \mathrm{mL}^{-1}\right)$. The proteins were quantified according to Bradford (1976).

The analysis of the nitrogenase enzyme activity was evaluated indirectly by acetylene reduction activity (ARA), according to the method described by Boddey (1987). Pure colonies of isolates were cultured in DYGS medium under constant agitation for $24 \mathrm{~h}$. The protein content was determined by the method described by Bradford (1976). Protein concentration was estimated using a standard curve obtained through known quantities of bovine serum albumin (0.25 at $1.5 \mu \mathrm{g}$ of BSA).

The data were subjected to homogeneity and normality tests and variance analysis; means were 
compared by Scott-Knott's test at $5 \%$ of significance, using software Sisvar version 4.0 (Ferreira, 2000).

\section{RESULTS AND DISCUSSION}

For $\mathrm{N}$ fertilization, no significant effects were observed on the variable shoot dry weight (SDW), since the accumulation observed was due to inoculation with diazotrophic bacteria. Strain ZAE94 of $H$. seropedicae induced a significant increase $(14.33 \%)$ in the accumulation of SDW in hybrid AG1051, compared to the non-inoculated treatment (Table 1). In general, dry matter production was highest in the treatments with diazotrophic bacteria inoculation. This may be due to the ability of these bacteria to promote plant growth through the synthesis of phytohormones, stimulating the early plant growth. These microorganisms can cause morphological and physiological changes in root structure, contributing to increased water and nutrient uptake. According to Bastian et al. (1998), the species H. seropedicae can promote plant growth in Poaceas.

Similar results were obtained by Quadros (2009), who observed increases of $19.71 \%$ in maize shoot dry weight, in the hybrids AS 1575 and SHS 5050 inoculated with diazotrophic bacteria. Ramos et al. (2010) found that 30 DAP, maize plants inoculated with Azospirillum lipoferum (strain BR 11084) and fertilized with $30 \mathrm{~kg} \mathrm{~N}$ showed significant differences in SDW when compared to the control treatment. On the other hand, Reis Junior et al. (2008) found no significant effects of $A$. amazonense inoculation on the SDW of maize plants.

With regard to nitrogen percentage $(\mathrm{N} \%)$ in the SDW of the maize hybrid AG 1051, significant increases due to $\mathrm{N}$ fertilization were only observed at the rate of $100 \mathrm{~kg} \mathrm{ha}^{-1} \mathrm{~N}$. A quadratic regression model was fit for $\mathrm{N} \%$, which showed that the highest $\mathrm{N}$ content $(2.79 \%)$ can be obtained by fertilization with $109 \mathrm{~kg} \mathrm{ha}^{-1} \mathrm{~N}$ (Figure 1a). No significant effect of inoculation was observed on $\mathrm{N} \%$ in maize shoots (Table 1). Different results were obtained by Sabino (2003), who found increases of up to $34 \%$ in $\mathrm{N} \%$ of shoots of rice cultivar IR42 inoculated with strain ZAE94 and supplemented with $40 \mathrm{~kg} \mathrm{~N}$.
However, Dotto et al. (2010) observed that bacteria inoculation with genus Herbaspirillum induced no increase in $\mathrm{N}$ content in maize plants.

Regarding NTotal in plant tissue, inoculation with strain ZAE94 associated with the $60 \mathrm{~kg}$ $\mathrm{N}$ rate promoted increases of $44.32 \%$ over the non-inoculated control. In turn, in treatments supplemented with 100 and $140 \mathrm{~kg} \mathrm{~N}$, although statistically different, inoculation induced no marked increases (Figure 1b). In both treatments, a quadratic adjustment was observed. These results reveal that the accumulation in NTotal observed in maize shoots resulted from an increased shoot dry mass, induced by inoculation with strain ZAE94.

Sabino (2003) observed that ZAE94 inoculation, along with $80 \mathrm{~kg} \mathrm{ha}^{-1} \mathrm{~N}$, promoted significant increases in NTotal accumulation in shoots over the control treatment. Guimarães et al. (2003) also observed that ZAE94 inoculation provided increases of $86 \%$ in NTotal in rice shoots, although these values were not significant. Ferreira et al. (2010), testing the wheat variety BRS 296 inoculated with strain Sp245 along with a $40 \mathrm{~kg} \mathrm{ha}^{-1} \mathrm{~N}$ rate also observed significant differences in NTotal of shoots over the non-inoculated control (average increase $23.2 \%$ ).

In general, the results suggested that the significant effect of inoculation on the variables under study may have been a result of the action of $\mathrm{N}$-fixing diazotrophic bacteria that are also plant growth promoters.

Another important factor is the specificity of the diazotrophic bacterium used, considering that it was isolated when endophytically colonizing roots of maize, sorghum, and rice (Baldani et al., 1986). Recent studies demonstrated that the species $H$. seropedicae provided significant results in several commercially relevant agricultural crops (Reis et al., 2005).

\section{Isolation and count of diazotrophic bacteria}

The result of isolation and count by means of the NMP technique showed that there were variations in the occurrence of diazotrophic bacteria in the root and shoot fragments of maize plants. Of a total of 30 isolates, $80 \%$ were found in roots and $20 \%$ in shoots. Analyses by semi-specific media and

Table 1. Height, dry mass, percentage N (N\%), and total N (NTotal) of shoots of maize plants inoculated or not with the diazotrophic bacterium $H$. seropedicae (strain ZAE94) grown in Vitória da Conquista, average of five replications

\begin{tabular}{lcccc}
\hline Treatment & Height & Dry matter & N\% & NTotal \\
\hline & $\mathrm{cm}$ & $\mathrm{g}$ & dag kg-1 & $\mathrm{g} / \mathrm{plant}$ \\
Strain ZAE 94 (inoculated) & $36.27 \mathrm{~A}$ & $13.48 \mathrm{~A}$ & $2.14 \mathrm{~B}$ & $30.29 \mathrm{~A}$ \\
Control (uninoculated) & $32.54 \mathrm{~A}$ & $11.79 \mathrm{~B}$ & $2.40 \mathrm{~A}$ & $29.07 \mathrm{~A}$ \\
\hline
\end{tabular}

Mean values followed by the same letter in the column do not differ by Tukey's test at $5 \%$ of significance. 
(a)

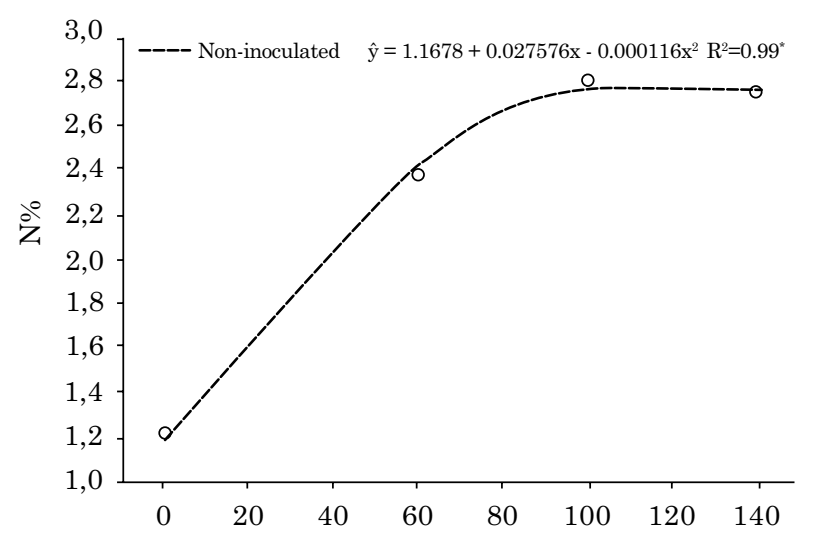

(b)

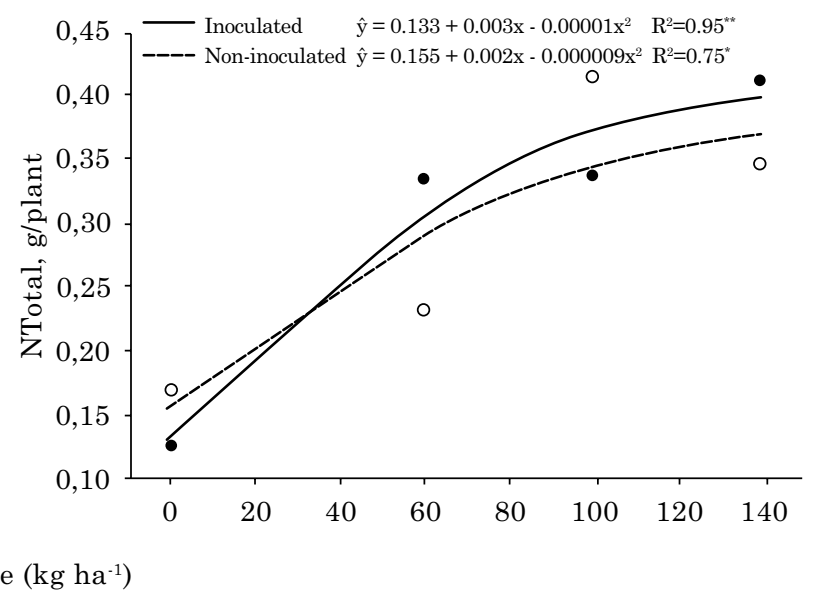

Figure 1. Nitrogen percentage (N\%) (a) and nitrogen total (NTotal) (b) in maize shoots, with and without inoculation (ZAE94) and different $\mathrm{N}$ rates, in Vitória da Conquista, average of five replications.

morphological characterization suggested that $50 \%$ of the isolates are similar to bacteria from genera or species of Herbaspirillum and $50 \%$ of Azospirillum. However, for confirmation at the level of genus or even species to which the isolates belong, analyses by molecular techniques are required.

The results corroborate previous studies that reported the occurrence of diazotrophic bacteria in crops such as maize (Roesch et al., 2007; Gomes et al., 2010), rice (Sabino, 2003; Viana, 2012), and sugarcane (Antonio, 2010), in which an increased number of diazotrophic bacteria was found in roots. According to Dobbelaere et al. (2003), the root region, for being a nutrient-rich environment, favors the activity and growth of microorganisms, which will use the organic compounds released by root exudation and deposition, as energy and carbon sources.

It was not possible to identify any isolate similar to that of the species $A$. amazonense by morphological characterization, although the culture medium LGI (indicated for the species) showed the occurrence of diazotrophic bacteria in roots and shoots.

These results suggest that isolates were possibly not reactivated, due to the loss of bacteria viability in the period they remained in stock or maybe the culture medium recommended exclusively for isolation of this species failed to make a detection possible, since the culture media are regarded as semi-specific.

Sala et al. (2005) studied the diversity of diazotrophic bacteria in wheat plants but detected no microorganisms in culture medium LGI-P, indicated to isolate $G$. diazotrophicus species, in spite of the characteristic layers observed in the culture medium.
Under the same test conditions, no occurrence of diazotrophic bacteria was observed in culture medium JMV, indicated for bacteria of the genus Burkholderia.

All 30 isolates obtained were able to produce indole compounds in L-tryptophan supplemented culture medium. In general, the production of IAA by isolates similar to the genera Herbaspirillum and Azospirillum spp. ranged from 0.269 to $15.649 \mu \mathrm{g} \mathrm{mg}^{-1}$ of protein (Table 2).

In all isolates, IAA was detected, however, the production of those similar to the genus Herbaspirillum spp. was lower than of those similar to Azospirillum spp. These results corroborate those of Radwan et al. (2004), who found that isolates of Azospirillum produce more indole compounds than those of Herbaspirillum.

Among isolates similar to those of genus Herbaspirillum spp., IAA production ranged from 0.269 to $11.246 \mu \mathrm{g} \mathrm{mg-1}$ of protein and of those similar to genus Azospirillum spp. from 1.234 to $15.649 \mu \mathrm{g} \mathrm{mg-1}$ of protein. These results were similar to those found by Pedraza et al. (2004), who, by evaluating the ability of five isolates of Azospirillum spp., observed an IAA production from 2.680 to $38.286 \mu \mathrm{g} \mathrm{mg-1}$ of protein, and Bergamaschi et al. (2007), who reported values from 0.70 to $10.70 \mu \mathrm{g} \mathrm{mg-1}$ of protein for diazotrophic bacteria isolated from sorghum (Table 2).

The strains N11 and N13 stood out regarding the production of IAA, with values statistically equal to the standard strain of $H$. seropedicae (ZAE94) and higher than the other strains. The biosynthesis of IAA is part of the metabolism of various species of bacteria associated with plants (Patten and 
Table 2. Acetylene reduction activity (ARA), synthesis of indole acetic acid (IAA) by native strains isolated from maize plants AG 1051 and standard bacteria

\begin{tabular}{|c|c|c|c|c|}
\hline Isolate & ARA & AIA & Plant component & Culture medium \\
\hline & $\mathrm{mmol} \mathrm{h}^{-1} \mathrm{mg}^{-1}$ of protein & ug $\mathrm{mg}^{-1}$ of protein & & \\
\hline UESBN1 & $1.7084 \mathrm{c}$ & $5.3923 \mathrm{~d}$ & Root & $\mathrm{NFb}$ \\
\hline UESBN2 & $2.1438 \mathrm{c}$ & $5.5390 \mathrm{~d}$ & Root & $\mathrm{NFb}$ \\
\hline UESBN3 & $1.3153 \mathrm{c}$ & $6.5483 \mathrm{c}$ & Root & $\mathrm{NFb}$ \\
\hline UESBN4 & $2.1017 \mathrm{~b}$ & $2.9423 \mathrm{e}$ & Root & $\mathrm{NFb}$ \\
\hline UESBN5 & $0.0428 \mathrm{c}$ & $1.2343 \mathrm{e}$ & Shoot & $\mathrm{NFb}$ \\
\hline UESBN6 & $\mathrm{Nd}$ & $1.9773 \mathrm{e}$ & Shoot & $\mathrm{NFb}$ \\
\hline UESBN7 & $2.8579 \mathrm{~b}$ & $7.0870 \mathrm{c}$ & Root & $\mathrm{NFb}$ \\
\hline UESBN8 & $2.6939 \mathrm{~b}$ & $6.7760 \mathrm{c}$ & Shoot & $\mathrm{NFb}$ \\
\hline UESBN9 & $2.7339 \mathrm{~b}$ & $7.3426 \mathrm{c}$ & Shoot & $\mathrm{NFb}$ \\
\hline UESBN10 & $1.5782 \mathrm{c}$ & $4.5596 \mathrm{~d}$ & Shoot & $\mathrm{NFb}$ \\
\hline UESBN11 & $\mathrm{Nd}$ & $15.6496 \mathrm{~d}$ & Shoot & $\mathrm{NFb}$ \\
\hline UESBN12 & $0.9145 \mathrm{c}$ & $11.7833 \mathrm{~b}$ & Root & $\mathrm{NFb}$ \\
\hline UESBN13 & $2.3515 \mathrm{~b}$ & $14.2116 \mathrm{a}$ & Root & $\mathrm{NFb}$ \\
\hline UESBN14 & $0.3577 \mathrm{c}$ & $9.5226 \mathrm{~b}$ & Root & $\mathrm{NFb}$ \\
\hline UESBN15 & $4.3543 \mathrm{a}$ & $3.6013 \mathrm{e}$ & Root & $\mathrm{NFb}$ \\
\hline UESBJ1 & $0.8599 \mathrm{c}$ & $5.9120 \mathrm{~d}$ & Root & $\mathrm{JNFb}$ \\
\hline UESBJ2 & $0.8894 \mathrm{c}$ & $6.5533 \mathrm{c}$ & Root & $\mathrm{JNFb}$ \\
\hline UESBJ3 & $\mathrm{Nd}$ & $0.2686 \mathrm{e}$ & Root & $\mathrm{JNFb}$ \\
\hline UESBJ4 & $0.8643 \mathrm{c}$ & $8.6676 \mathrm{c}$ & Shoot & $\mathrm{JNFb}$ \\
\hline UESBJ5 & $0.7939 \mathrm{c}$ & $5.3703 \mathrm{~d}$ & Root & $\mathrm{JNFb}$ \\
\hline UESBJ6 & $1.2948 \mathrm{c}$ & $5.8583 \mathrm{~d}$ & Root & $\mathrm{JNFb}$ \\
\hline UESBJ7 & $0.8713 \mathrm{c}$ & $6.9230 \mathrm{c}$ & Root & $\mathrm{JNFb}$ \\
\hline UESBJ8 & $1.0889 \mathrm{c}$ & $9.7990 \mathrm{~b}$ & Root & $\mathrm{JNFb}$ \\
\hline UESBJ9 & $0.7362 \mathrm{c}$ & $11.2463 \mathrm{~b}$ & Root & $\mathrm{JNFb}$ \\
\hline UESBJ10 & $1.0767 \mathrm{c}$ & $6.4453 \mathrm{c}$ & Root & $\mathrm{JNFb}$ \\
\hline UESBJ11 & $0.9493 \mathrm{c}$ & $8.4286 \mathrm{c}$ & Root & $\mathrm{JNFb}$ \\
\hline UESBJ12 & $0.8922 \mathrm{c}$ & $5.8163 \mathrm{~d}$ & Root & $\mathrm{JNFb}$ \\
\hline UESBJ13 & $0.7470 \mathrm{c}$ & $4.3853 \mathrm{~d}$ & Root & $\mathrm{JNFb}$ \\
\hline UESBJ14 & $0.6195 \mathrm{c}$ & $4.9546 \mathrm{~d}$ & Root & $\mathrm{JNFb}$ \\
\hline UESBJ15 & $0.7288 \mathrm{c}$ & $7.7493 \mathrm{c}$ & Root & $\mathrm{JNFb}$ \\
\hline $\mathrm{Sp} 245$ & $0.6431 \mathrm{c}$ & - & Standard & $\mathrm{NFb}$ \\
\hline ZAE94 & - & $15.7853 \mathrm{a}$ & Standard & $\mathrm{JNFb}$ \\
\hline
\end{tabular}

Same letters in the same column do not differ significantly from each other by the Scott-Knott test at $5 \%$ significance. Nd: not detected.

Glick, 1996), providing these microorganisms with the ability to stimulate and promote plant growth.

The nitrogenase enzyme activity, responsible for $\mathrm{BNF}$, may be indirectly measured by the acetylene reduction technique. Therefore, out of the 30 native isolates, 28 isolates obtained detectable ARA from 0.013 to $4.354 \mathrm{nmol} \mathrm{C}_{2} \mathrm{H}_{4} \mathrm{~h}^{-1} \mathrm{mg}^{-1}$ of protein. Under the test conditions, strains similar to the genus Herbaspirillum spp. obtained ARA between
0.6196 and $1.29492949 \mathrm{nmol} \mathrm{C}_{2} \mathrm{H}_{4} \mathrm{~h}^{-1} \mathrm{mg}^{-1}$ of protein. Those similar to the genus Azospirillum showed variation between 0.013 and $4.354 \mathrm{nmol}$ $\mathrm{C}_{2} \mathrm{H}_{4} \mathrm{~h}^{-1} \mathrm{mg}^{-1}$ of protein. For ARA production, the isolates that stood out were J06, J08, and J10, morphologically characterized as similar to the genus Herbaspirillum spp. and N15, morphologically characterized as belonging to the genus Azospirillum spp. However, N15 obtained 
the highest value of ARA production under in vitro conditions, demonstrating potential to be used in inoculation tests (Table 2).

In the literature, there are mixed results regarding the ability to reduce acetylene to ethylene between strains of a same species. Rodrigues et al. (2006) observed a large variation in the detection of ARA in bacteria from the genera Herbaspirillum and Burkholderia, isolated from rice plants. VIANA (2012) evaluated isolates similar to Herbaspirillum for ARA, detected values with amplitude from 16.559 to $199.717 \mathrm{nmol}$ $\mathrm{C}_{2} \mathrm{H}_{4} \mathrm{~h}^{-1} \mathrm{mg}^{-1}$ of protein. Pedrinho (2009), studying the ability to reduce acetylene in bacteria isolated from maize plants, obtained ARA values between 0.1 and $0.64 \mathrm{nmol}_{2} \mathrm{H}_{4}$ culture $-1 \mathrm{~h}^{-1}$, of bacteria from the genera Pseudomonas sp, Herbaspirillum sp, Burkholderia sp, and Sphingomonas sp.

The bacteria isolated in this study, for being native, may have more interactions with maize plants grown in situ, allowing greater contribution of BNF to the crop. According to Baldani and Baldani (2005), studies show that strains isolated from a species are more likely to reestablish on roots when inoculated on the same plant species, and are called homologous strains.

\section{CONCLUSIONS}

Inoculation with strain ZAE94 promoted, under greenhouse conditions, increases of $14.33 \%$ in shoot dry weight and, when inoculation was supplemented with $60 \mathrm{~kg} \mathrm{~N}$, increases of $44.32 \%$ in NTotal of maize plants.

The diazotrophic bacteria ZAE94 is promising for testing under local edaphoclimatic conditions.

It was possible to obtain 30 isolates under the local edaphoclimatic conditions.

The new isolates $\mathrm{J} 10, \mathrm{~N} 13$, and N15, derived under the local conditions, proved promising for further studies, where their effectiveness must be tested in field experiments.

\section{ACKNOWLEDGEMENTS}

The authors thank the field board of directors and all its contributors, for their assistance during the experiment, the Foundation for Research Support of the State of Bahia (FAPESB), for granting a scholarship, and the Southwest Bahia State University (UESB), for its collaboration in carrying out this research.

\section{REFERENCES}

Alvarez V. VH, Ribeiro AC. Calagem. In: Ribeiro AC, Guimarães PTG, Alvarez V VH, editores. Recomendação para o uso de corretivos e fertilizantes em Minas Gerais: 5a Aproximação. Viçosa, MG: Comissão de Fertilidade do Solo do Estado de Minas Gerais; 1999. p.41-60.

Alves GC. Efeito da Inoculação de bactérias diazotróficas dos gêneros Herbaspirillum e Burkholderia em genótipos de milho [dissertação]. Seropédica: Universidade Federal Rural do Rio de Janeiro; 2007.

Amado TJC, Mielniczuk J, Aita C. Recomendação de adubação nitrogenada para o milho no RS e SC adaptada ao uso de culturas de cobertura do solo, sob sistema plantio direto. $\mathrm{R}$ Bras Ci Solo. 2002;26:241-8.

Antonio CS. Ocorrência de bactérias endofíticas associadas a variedades de cana-de-açúcar cultivadas nos estados: Alagoas e Pernambuco [dissertação]. Seropédica: Universidade Federal Rural do Rio de Janeiro; 2010.

Baldani JI, Baldani VLD. History on the biological nitrogen fixation research in graminaceous plants: Special emphasis on the Brazilian experience. An Acad Bras Ci. 2005;77:549-79.

Baldani VLD, Baldani JI, Dobereiner J. Inoculation of rice plants with endophytic diazotrophs Herbaspirillum seropedicae and Burkholderia spp.. Biol Fert Soils. 2000;30:485-91.

Baldani JI, Baldani VLD, Seldin L, Dobereiner J. Characterization of Herbaspirillum seropedicae gen. nov., sp. nov., a new rootassociated nitrogen fixing bacterium. Int J Syst Bacteriol. 1986;36:86-93.

Bastian F, Cohen A, Piccoli P, Luna V, Baraldi R, Bottini R. Production of indole-3-acetic and gibberellins A1 and A3 by Acetobacter diazotrophicus and Herbaspirillum seropedicae in chemically defined culture media. J Plant Growth Regul. 1998;24:7-11.

Bradford MM. A rapid and sensitive for the quantitation de microgram quantities of protein utilizing the principle of proteindye binding. Anal Biochem. 1976;72:248-54.

Brasil. Ministério da Agricultura e Reforma Agrária. Normais climatológicas. 1961-1990. Brasília, DF; 1992.

Bergamaschi L, Roesch LFW, Quadros PD, Camargo FAO. Ocorrência de bactérias diazotróficas associadas a cultivares de sorgo forrageiro. Ci Rural. 2007;37:727-33.

Boddey RM. Methods for quantification of nitrogen fixation associated with gramineae. Crit Rev Plant Sci. 1987;6:209-66.

Cavallet LE, Pessoa ACS, Helmich JJ, Helmich PR, Ost CF. Produtividade do milho em resposta à aplicação de nitrogênio e inoculação das sementes com Azospirillum spp. R Bras Eng Agríc Amb. 2000;4:129-32.

Companhia Nacional de Abastecimento - Conab. Levantamento da safra brasileira de grãos 2012/13 - Oitavo levantamento, maio 2013. Brasília, DF: Ministério da Agricultura, Pecuária e Abastecimento; 2013.

Conceição PM, Vieira HD, Canellas LP, Olivares FL, Conceição PS. Efeito dos ácidos húmicos na inoculação de bactérias diazotrófícas endofíticas em sementes de milho. Ci Rural. 2009;39:1880-3. 
Dobbelaere S, Vanderleyden J, Okon Y. Plant growth promoting effects of diazotrophs in the rhizosphere. Crit Rev Plant Sci. 2003;22:107-49.

Döbereiner J, Baldani VLD, Baldani JI. Como isolar e identificar bactérias diazotróficas de plantas não-leguminosas. Brasília, DF: Empresa Brasileira de Pesquisa Agropecuária; 1995.

Dotto AP, Lana MC, Steiner F, Frandoloso JF. Produtividade do milho em resposta à inoculação com Herbaspirillum seropedicae sob diferentes níveis de nitrogênio. $\mathrm{R}$ Bras $\mathrm{Ci}$ Agron. 2010;5:376-82.

Ferreira DF. Análises estatísticas por meio do Sisvar para Windows versão 4.0. In: Anais da 45a Reunião Anual da Região Brasileira da Sociedade Internacional de Biometria; jul 2000; São Carlos. São Carlos: Universidade Federal de São Carlos; 2000. p.255-8.

Ferreira JS, Baldani JI, Baldani VLD. Seleção de inoculantes à base de turfa contendo bactérias diazotróficas em duas variedades de arroz. Acta Sci Agron. 2010;32:179-85.

Gomes ML, Perin L, Pereira GMD, Zilli JZ. Bactérias diazotróficas endofíticas em cultivares de milho em áreas de cerrado e mata 73 no estado de Roraima. Boa Vista: Empresa Brasileira de Pesquisa Agropecuária; 2010.

Guimarães SL, Baldani JI, Baldani VLD. Efeito da inoculação de bactérias diazotróficas endofíticas em arroz de sequeiro. $R$ Agron. 2003;37:25-30.

Hungria M, Campo RJ, Mendes IC. Fixação biológica do nitrogênio na cultura da soja. Londrina: Empresa Brasileira de Pesquisa Agropecuária; 2001. (Circular técnica, 35).

Kwiatkowski A, Clemente E. Características do milho doce (Zea mays L.) Para industrialização. R Bras Tecnol Agroind. 2009;1:93-103.

Moreira FMS, Silva K, Nobrega RSA, Carvalho F. Bactérias diazotróficas associativas: Diversidade, ecologia e potencial de aplicações. Com Sci. 2010;1:74-99.

Nogueira ARA, Souza GB. Manual de laboratórios: Solo, água, nutrição vegetal, nutrição animal e alimentos. São Carlos: Empresa Brasileira de Pesquisa Agropecuária; 2005.

Patten CL, Glick BR. Bacterial biosynthesis of indole-3-acetic acid. Can J Microbiol. 1996;42:207-20.

Pedraza RO, Ramírez-Mata A, Xiqui ML, Baca BE. Aromatic amino acid aminotransferase activity and indole-3-acetic acid production by associative nitrogen-fixing bacteria. FEMS Microbiol Lett. 2004;233:15-21.

Pedrinho EAN. Isolamento e caracterização de bactérias promotoras de crescimento em milho (Zea mays) [tese]. Jaboticabal: Universidade Estadual Paulista; 2009.
Quadros PD. Inoculação de Azospirillum spp. em sementes de genótipos de milho cultivados no Rio Grande do Sul [tese]. Porto Alegre: Universidade Federal Rural do Rio Grande do Sul; 2009.

Radwan TEE, Mohamed ZK, Reis VM. Efeito da inoculação de Azospirillum e Herbaspirillum na produção de compostos indólicos em plântulas de milho e arroz. Pesq Agropec Bras. 2004;39:987-94.

Ramos AS, Santos TMC, Santana TM, Guedes ELF, Montaldo YC. Ação do Azospirillum lipoferum no desenvolvimento de plantas de milho. R Verde. 2010;5:113-7.

Reis VM, Teixeira KRS. Fixação biológica de nitrogênio - estado da arte. In: Aquino AM, Assis RL, editores. Processos biológicos no sistema solo-planta: Ferramentas para uma agricultura sustentável. Brasília, DF: Empresa Brasileira de Pesquisa Agropecuária; 2005. p.151-80.

Reis Junior FB, Machado CTT, Machado AT, Sodek L. Inoculação de Azospirillum amazonense em dois genótipos de milho sob diferentes regimes de nitrogênio. R Bras Ci Solo. 2008;32:1139-46.

Rodrigues LS, Baldani VLD, Reis VM, Baldani JI. Diversidade de bactérias diazotróficas endofíticas dos gêneros Herbaspirillum e Burkholderia na cultura do arroz inundado. Pesq Agropec Bras. 2006;41:275-84.

Roesch LF, Quadros PDQ, Camargo FAO, Triplett EW. Screening of diazotrophic bacteria Azopirillum spp. for nitrogen fixation and auxin production in multiple field sites in southern Brazil. World J Microbiol Biotechnol. 2007;23:1377-83.

Sabino DCC. Metabolismo de nitrogênio em plantas de arroz (Oryza sativa L.) em associação com bactérias diazotróficas endofíticas [dissertação]. Seropédica: Universidade Federal Rural do Rio de Janeiro; 2003.

Sala VMR, Cardoso EJBN, Freitas JG, Silveira APD. Novas bactérias diazotróficas endofíticas na cultura do trigo em interação com a adubação nitrogenada, no campo. R Bras Ci Solo. 2008;32:1099-106.

Sala VMR, Freitas SS, Donzeli VP, Freitas JG, Gallo PB, Silveira APD. Ocorrência e efeito de bactérias diazotróficas em genótipos de trigo. R Bras Ci Solo. 2005;29:345-52.

Sarwar M, Kremer RJ. Enhanced suppression of plant growth through production of L-tryptophan-derived compounds by deleterious rhizobacteria. Plant Soil. 1995;172:261-9.

Soratto RP, Pereira M, Costa TAM, Lampert VN. Fontes alternativas e doses de nitrogênio no milho safrinha em sucessão à soja. R Ci Agron. 2010;41:511-8.

Viana TO. Isolamento e inoculação de bactérias diazotróficas em arroz (Oryza sativa L.) cultivado em Vitória da Conquista - BA [tese]. Vitória da Conquista: Universidade Estadual do Sudoeste da Bahia; 2012. 